IRSTI 06.77.64

UDC 331.5

https://doi.org/10.46914/1562-2959-2021-1-1-172-178

\author{
A.T. RAKHMATULLINA, ${ }^{\text {* }}$ \\ Master, PhD student. \\ *e-mail: rakhmatullina.alina@gmail.com \\ D.D. YERMEKBAYEVA, ${ }^{1}$ \\ $\mathrm{PhD}$, associate professor. \\ e-mail: ermekbaevad@mail.ru \\ P. HÁJEK. ${ }^{2}$ \\ $\mathrm{PhD}$, assistant professor. \\ e-mail: hajekp@gmail.com \\ ${ }^{1}$ University of International Business \\ ${ }^{2}$ Unicorn University, Czech Republic, Prague \\ ${ }^{2}$ European Institute of Applied Science \\ and Management, Czech Republic, Prague
}

\title{
THE DYNAMICS OF THE LABOUR MARKET AND EMPLOYMENT IN EAEU COUNTRIES
}

\begin{abstract}
The labour market is a fundamental element of the economy of any country, and the functioning of the national economy depends on its dynamics and state. In the context of deepening globalization processes in the world economy, which are manifested in the growing interdependence of countries and their regional groupings, national labour markets, like markets for goods, services and capital, are increasingly losing their isolation, which leads to the formation of the so-called common labour market. The common labour market of the Eurasian Economic Union is something qualitatively new. National labour markets are losing their isolation, and an integrated labour market is becoming a national entity. Its formation is based on the mobility of citizens of the states that have joined the Eurasian Economic Union, provided by the instruments of coordinated migration and social policies, the international legal framework for regulating the labour market, which are focused on maintaining a balance of economic and social interests of the countries of the integration union. This work reflects the dynamics of the development of the labour market and employment of the EAEU member states, identifies the problematic links of the new integration space. Key attention is directed to the analysis of the economically active population, as well as a separate analysis of the employed/ unemployed population, the level of wages of each EAEU member state. The authors noticed the main points of the differences in the dynamics of the development of the above indicators.
\end{abstract} activity.

Key words: Eurasian Economic Union; labour market; employment, unemployment, remuneration, population,

Due to the entry into the EAEU and the formation of the labor market, new opportunities are opening up for the EAEU member countries. These prospects are primarily associated with the freedom of movement of goods and services, as well as labor. An important component of the Eurasian Economic Community is the common labor market [1].

The common labor market of the EAEU is qualitatively new. National labor markets are losing their isolation, an integrated resource market by national education. It is based on the mobility of citizens of the states that have joined the Eurasian Economic Union, provided by the instruments of coordinated migration and social policies, the international legal framework for regulating the labor market, which are focused on maintaining the balance of economic and social countries of the united community. The general labor market deals with the human factor, with the specifics of the psychophysiological behavior of people. Labor power as a commodity has no alternative. The disproportions in the distribution of the active population in the Eurasian Economic Union between countries exist now and will persist in the future [2]. Let us consider the dynamics of the economically active population among the EAEU member countries in Table 1 (p. 173). 
Table 1 - Number of economically active population (thousands of people), 2007-2019

\begin{tabular}{|l|c|c|c|c|c|c|c|c|c|c|c|c|c|}
\hline & 2007 & 2008 & 2009 & 2010 & 2011 & 2012 & 2013 & 2014 & 2015 & 2016 & 2017 & 2018 & 2019 \\
\hline Armenia & 1184,3 & 1414,6 & 1418,8 & 1463,3 & 1440,9 & 1418,3 & 1388,4 & 1375,7 & 1316,4 & 1226,3 & 1230,8 & 1141,5 & 1318,1 \\
\hline Belarus & 4566,9 & 4654,2 & 4686,1 & 4742,2 & 4722,7 & 4640,6 & 4601,8 & 4572,8 & 4537,3 & 5163,6 & 5195,3 & 5141,6 & 5122,4 \\
\hline & & & & & & & & & & & & & \\
Kazakhstan & 8228,3 & 8415 & 8457,9 & 8610,7 & 8774,6 & 8981,9 & 9041,3 & 8962,2 & 9074,9 & 8998,8 & 9027,4 & 9138,6 & 9221,5 \\
\hline & & & & & & & & & & & & & \\
Kyrgyzstan & 2343,3 & 2379,9 & 2420,1 & 2456 & 2490,1 & 2496,8 & 2468,7 & 2504,2 & 2544,3 & 2547,4 & 2525,2 & 2538,8 & 2583,6 \\
\hline Russia & 75288,9 & 75700,1 & 75694,2 & 75477,9 & 75779 & 75676,1 & 75528,9 & 75428,4 & 76587,5 & 76636,1 & 76285,4 & 76190,1 & 75397,9 \\
\hline EAEU & 91611,7 & 92563,8 & 92677,1 & 92750,1 & 93207,3 & 93213,7 & 93029,1 & 92843,3 & 94060,4 & 94572,2 & 94264,1 & 94150,6 & 93643,5 \\
\hline
\end{tabular}

Analysis of Table 1 shows that during the specified period, the following trend is observed: the number of economically active population / labor force in the EAEU countries in 2019 compared to 2007-2019 increased by 2,031 thousand people. The average total number of the economically active population / labor force of the EAEU countries for the analyzed period is 94,000 thousand people, while over $75 \%$ of the population is involved in economic activity in Belarus, Kazakhstan and Russia, in Kyrgyzstan - 63.6\%, in Armenia - 56.6\% [4].

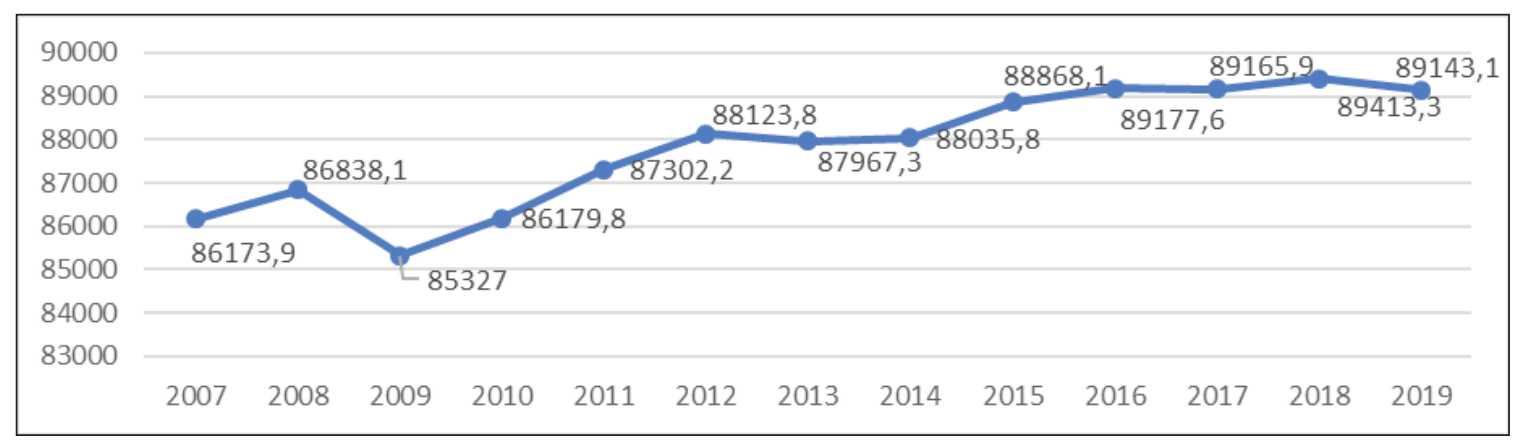

Figure 1 - Employed population in the EAEU, 2007-2019

Note - Source: Compiled on the base of [4].

The number of the employed population in the EAEU during the analyzed period increased from $86,173.9$ thousand to 89413.3 thousand, or by 3239.4 thousand. The analysis of the Figure 1 shows that in 2009 the lowest indicator was 85327.0 thousand people. This was due to the global economic crisis, which affected all the EAEU countries.

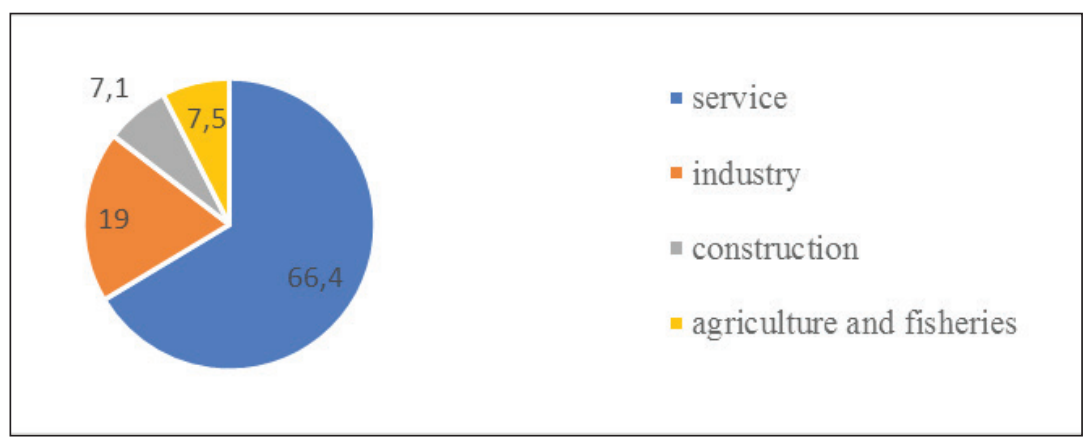

Figure 2 - Distribution of the employed population by field of activity in 2019

Note - Source: Compiled on the base of [4]. 
According to the official data, in the EAEU countries a large share of the employed is in the service sector. If we take each state separately, we get a mixed picture.

Analyzing male and female employment by type of economic activity, it can be noticed that there are significant differences in this distribution. The share of women in the employed population was over $70 \%$ in the following types of economic activities: education: in Russia $-82.0 \%$, Kyrgyzstan $79.6 \%$, Armenia $-78.4 \%$, in Kazakhstan $-73.7 \%$; healthcare and social services: in Kyrgyzstan $83.3 \%$, Armenia $-81.4 \%$, Russia $-79.3 \%$, in Kazakhstan $-74.0 \%$; accommodation and catering services: in Russia $-73.5 \%$; operations with real estate: in Kyrgyzstan $-87.7 \%$.

A high proportion of men (over 70\%) has developed in such types of economic activities as: mining and quarrying: in Armenia - 91.3\%, Kyrgyzstan - 90.6\%, Russia - 82.6\%, in Kazakhstan 79.9\%; power supply, gas, steam and air conditioning: in Kyrgyzstan $-89.7 \%$, Armenia $-79.5 \%$, Russia-74.4\%; water supply; sewerage system, control over the collection and distribution of waste: in Armenia - 74.3\%, Kyrgyzstan - 72.9\%; construction: in Armenia - 98.0\%, Kyrgyzstan - 97.2\%, Russia - 86.3\%, in Kazakhstan - 77.8\%; transport and warehousing: in Kyrgyzstan - 95.1\%, Armenia $82.3 \%$, in Kazakhstan $-78.7 \%$, Russia $-77.3 \%$; public administration and defense, compulsory social security: in Armenia - 75.6\%.

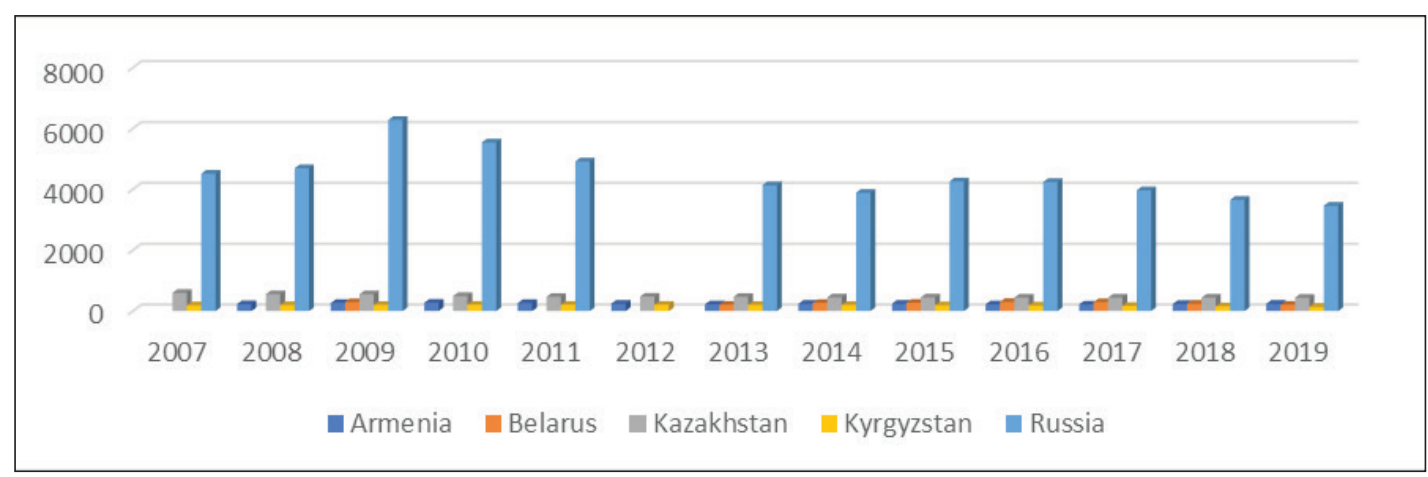

Figure 3 - Dynamics of the number of unemployed in the EAEU countries, thousand people for 2007-2019

Note - Source: Compiled on the base of [4].

It should be noted that the minimum wage of the unemployed plays an important role in reducing the unemployment rate in the EAEU countries. Statistical data 2005-2019 show small changes in the indices of nominal wages in the EAEU countries (Figure 5).

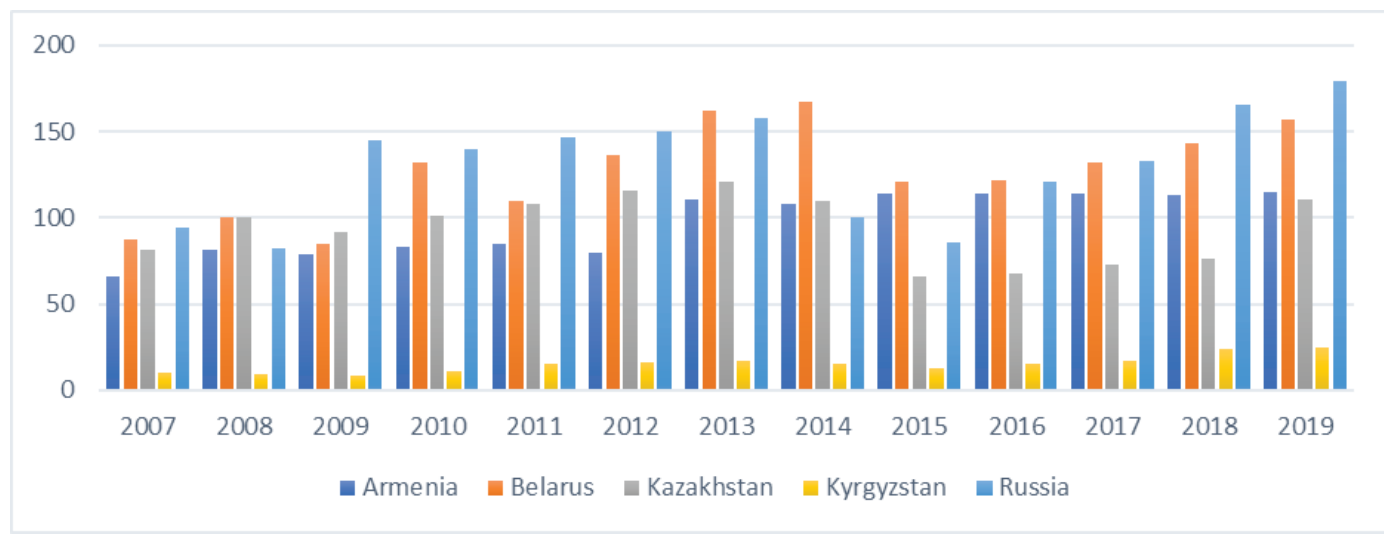

Figure 4 - Minimum wage in the EAEU countries, 2007-2019

Note - Source: Compiled on the base of [5]. 


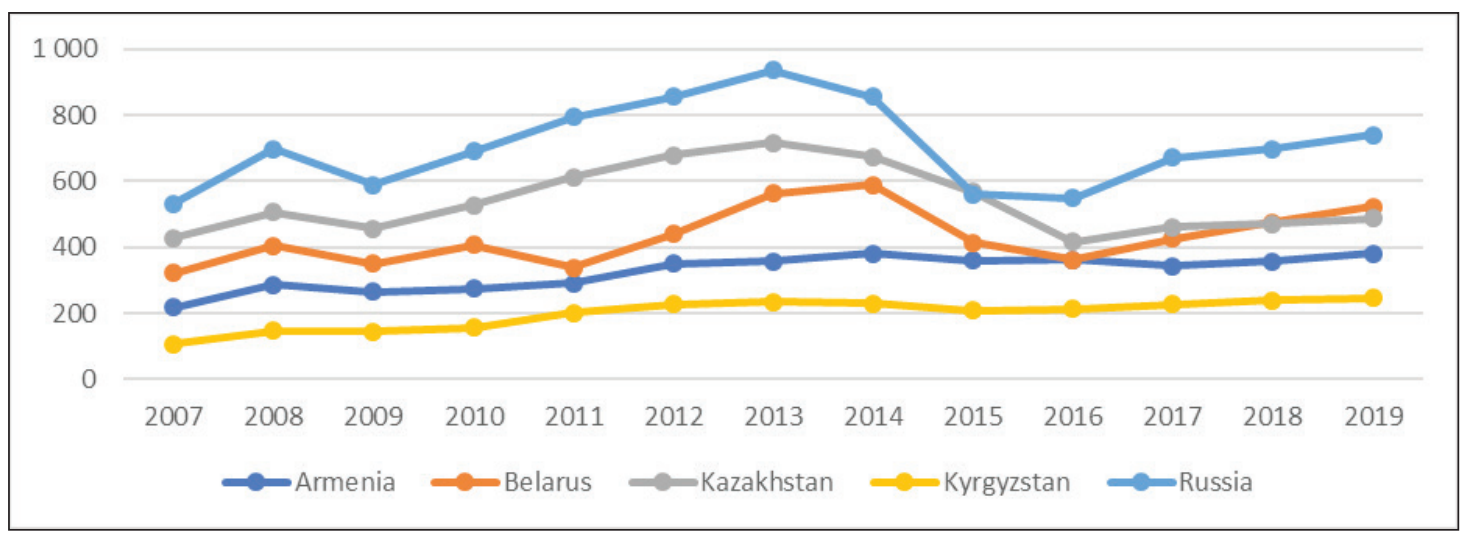

Figure 5 - Average monthly nominal wages in the EAEU countries, 2007-2019

Note - Source: Compiled on the base of [5].

Many scientists and experts argue that in the EAEU countries, about $40 \%$ of the economically active population is employed in the informal economyб they are covered by work of agreement. Everyone knows that many professions will disappear in the future. Of course, this will affect the national labor markets in the EAEU [3]. Obviously, the dynamics and state of the market depend on the average monthly nominal wages (Figure 5).

In Figure 6 below, it can be seen that for the analyzed period, the highest unemployment rate is observed in Armenia (20.5\%), followed by Kyrgyzstan (6.2\%). Armenia has the highest unemployment rate among the rest of the EAEU countries, which means that most qualified specialists cannot get a decent job, and therefore they move to other countries, for example, most migrate to Russia for the purpose of employment. It should be noted that the unemployment rate in the EAEU countries depends on labor migration. Due to the fact that the Russian market is open to labor migrants, this makes it possible to mitigate the situation with unemployment in countries such as, for example, Kyrgyzstan, where there has traditionally been a high level of unemployment.

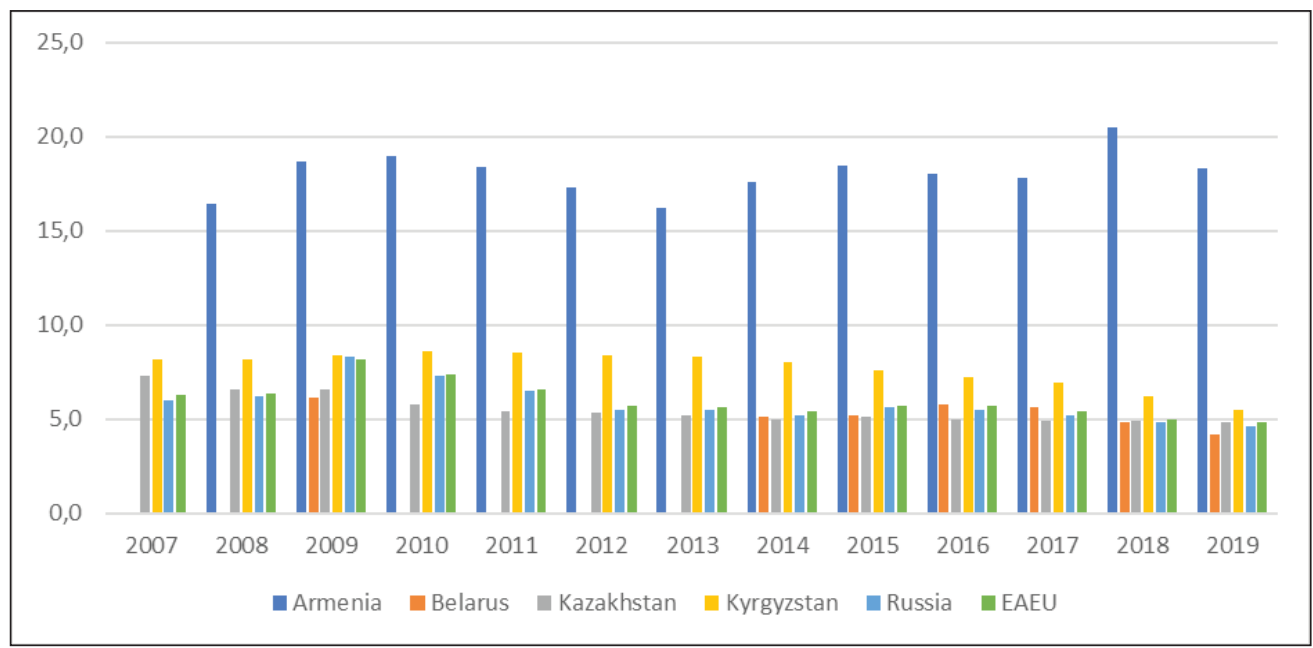

Figure 6 - Unemployment rate in the EAEU countries, 2007-2019

Note - Source: Compiled on the base of [5].

The EAEU labor market is heterogeneous and in the light of the formation of a new social class, which faces new challenges of the digital transformation of society. The problem of employer and employee needs to be re-examined. It is necessary to create conditions for the self-employed to get out of the shadows, as well as coordinate the flows of labor resources and their possible distribution within the framework of the EAEU unified migration policy in accordance with Article 97 of the Treaty on the Eurasian Economic Union (according to it, migrant workers from the states participating in the EAEU have equal employment rights). 
In this regard, we can say that employment is the most important factor affecting the welfare of the population. It influences the emergence of such a socio-economic factor as unemployment, which affects millions of people around the world. In most countries, low wages and unemployment are driving people's lives into poverty and their main goal is to find a way out of the economic deadlock. The modern labor market in Kazakhstan is characterized by an average level of unemployment and at the same time, there is a shortage of qualified personnel. The reasons for the decline in employment can be such factors as dynamic changes in the economy, which are associated with the crisis, as well as a decrease in economic growth. The decline in the level of economic activity has an impact on the reduction in the level of employment in sectors, which include agriculture, construction, industry and many others.

According to the Law on Employment of the Population, an employed person is an individual who carries out activities for payment or by generating income through the use of property, production and sale of goods, performance of work, and provision of services. The employment rate determines the degree of employment of the able-bodied population in the sphere of socially useful labor. The value of this indicator reflects the current economic situation in the country.

The government employment policy in the EAEU member states has a significant impact on the development of the EAEU labor market. Of course, this policy is aimed to prevent the rise in unemployment by mitigating the effects of unfavorable factors associated with the national labor market as well as preventing and eliminating the growth of unemployment.

Thus, the EAEU labor market is characterized by the following features:

- the movement of labor resources in the EAEU labor market conditionally occurs according to the stages of distribution, sale, development, retirement;

- free movement of labor across the territory of the EAEU is considered as a necessary prerequisite for the socio-economic development of not only the host country, but also the donor state;

- for all EAEU member states in terms of state regulation of employment, it is necessary to expand the use of social partnership in determining employment policies, introduce new information technologies in the field of employment, as well as develop practice-oriented and targeted education;

- the formation of the EAEU labor market is particularly influenced by informal employment. The main feature of informal employment is the lack of registration of labor relations, and, consequently, the vulnerability of workers involved in such relations.

In conclusion, we can say that today the EAEU is a perspective integration association and the functioning of the economy as a whole depends on the dynamics and state of the labor market. It must be emphasized that in order to deal with the difficulties arising in the labor market, government intervention is necessary, as well as the development of a supportive regulatory framework, which would provide new opportunities for both workers and employers. The implementation of these measures is intended to ensure an increase in the level of employment in general for both men and women in market conditions and to reduce the level of poverty to a minimum and the standard of living of the population to a maximum.

\section{LIST OF LITERATURE}

1 Sardaryan A.R., Petrochenko A.A. (2018) Modern state and problems of the labor market [Electronic source]. - URL: https://cyberleninka.ru/article/v/sovremennoe-sostoyanie-i-problemy-rynka-truda-v-stranaheaes.

2 Osadchaya G.I. (2017) International round table «Eurasian integration: problem links and points of growth» // Electronic scientific journal «Archon»- No. 1.

3 Akhatova E.Kh. (2014) Analysis of the current state and trends in the development of labor resources of the Republic of Kazakhstan // Multifaceted business assessment: problems and prospects in the formation of a knowledge-based economy. - No. 2 - P. 15-18.

4 ECE official statistics. The main indicators of the labor market of the EAEU [Electronic source]. - URL: http://www.eurasiancommission.org/ru/act/integr_i_makroec/dep_stat/union_stat/Pages/default.aspx.

5 Official statistical information of the EEC. Express information of the EAEU Department of Statistics. [Electronic source]. - URL: http://www.eurasiancommission.org/ru/act/integr_i_makroec/dep_stat/union_stat/ Pages/templates/express_demography.aspx. 
А.Т. РАХМАТУЛЛИНА, ${ }^{*}$ *

магистр, докторант.

*e-mail: rakhmatullina.alina@gmail.com

Д.Д. ЕРМЕКБАЕВА, ${ }^{1}$

$\mathrm{PhD}$ доцент.

e-mail: ermekbaevad@mail.ru

П. ХАЙЕК,

$\mathrm{PhD}$, ассистент профессор.

e-mail: hajekp@gmail.com

${ }^{1}$ Халыкаралык Бизнес Университеті, Қазақстан, Алматы қ.

${ }^{2}$ Уникорн Университеті, Чехия, Прага қ.

${ }^{2}$ Еуропалық қолданбалы ғылымдар

және менеджмент институты, Чехия, Прага қ.

\title{
ЕАЭО ЕЛДЕРІНДЕГІ ЕНБЕК НАРЫҒЫНЫН ЖӘНЕ ЖҰМЫСПЕН ҚАМТУДЫН ДАМУ ДИНАМИКАСЫ
}

\begin{abstract}
Андатпа
Еңбек нарығы кез-келген елдің экономикасының негізгі элементі болып табылады, ал ұлттық экономиканың жұмыс істеуі оның динамикасы мен күйіне байланысты. Елдердің және олардың аймақтық топтасуының өзара тәуелділігінің өсуінде көрінетін әлемдік экономикадағы жаһандану процестерінің тереңдеуі жағдайында тауарлар, қызметтер мен капитал нарықтары сияқты ұлттық еңбек нарықтары тұйықтығын және оқшаулануын барған сайын жоғалтуда, бұл жалпыға ортақ еңбек нарығының қалыптасуына алып келеді. Еуразиялық экономикалық одақтың ортақ еңбек нарығы - бұл сапалы жаңа нәрсе. Ұлттық еңбек нарықтары тұйықтығын, оқшаулануын жоғалтып, интеграцияланған еңбек нарығы ұлттық құрылымға айналуда. Оның қалыптасуы интеграциялық одақ елдерінің экономикалық және әлеуметтік мүдделерінің тепе-теңдігін сақтауға бағытталған келісілген көші-қон және әлеуметтік саясат құралдары, еңбек нарығын реттеудің халықаралыққұқықтық құралдары ұсынған Еуразиялық экономикалық одаққа кірген мемлекеттер азаматтарының ұтқырлығына негізделген. Бұл жұмыс ЕАЭО-ға мүше мемлекеттердің еңбек нарығының және жұмыспен қамтудың даму динамикасын көрсетеді, жаңа интеграциялық кеңістіктің проблемалық байланыстарын анықтайды. Негізгі назар экономикалық белсенді халықты талдауға, сондай-ақ Еуразиялық экономикалық комиссияның статистикалық деректері негізінде жұмыспен қамтылған халықты/жұмыссыздарды, ЕАЭО-ға мүше әр мемлекеттің жалақы деңгейін жеке талдауға бағытталған. Авторлар жоғарыда аталған көрсеткіштердің даму динамикасындағы айырмашылықтардың негізгі сәттерін байқап, оларға түсініктеме берді.
\end{abstract}

Тірек сөздер: Еуразиялық экономикалық одақ, еңбек нарығы, жұмыспен қамту, жұмыссыздық, жалақы, халық, қызмет.

\author{
А.Т. РАХМАТУЛЛИНА, ${ }^{1 *}$ \\ магистр, докторант. \\ *e-mail: rakhmatullina.alina@gmail.com \\ Д.Д. ЕРМЕКБАЕВА, ${ }^{1}$ \\ $\mathrm{PhD}$, доцент. \\ e-mail: ermekbaevad@mail.ru \\ П. ХАЙЕК ${ }^{2}$ \\ $\mathrm{PhD}$, ассистент профессор. \\ e-mail: hajekp@gmail.com \\ Чешская Республика, г. Прага
}

${ }^{1}$ Университет Международного Бизнеса, Казахстан, г. Алматы

${ }^{2}$ Университет Уникорн, Чешская Республика, г. Прага

${ }^{2}$ Европейский институт прикладных наук и менеджмента,

\section{ДИНАМИКА РАЗВИТИЯ РЫНКА ТРУДА И ЗАНЯТОСТИ В СТРАНАХ ЕАЭС}

\section{Аннотация}

Рынок труда является основополагающим элементом экономики любой страны, а от его динамики и состояния зависит функционирование национальной экономики. В условиях углубления глобализационных процессов в мировом хозяйстве, которые проявляются в росте взаимозависимости стран и их региональных 
группировок, национальные рынки труда, как и рынки товаров, услуг и капиталов, все больше теряют свою замкнутость и обособленность, что приводит к образованию так называемого общего рынка труда. Общий рынок труда Евразийского экономического союза представляет собой нечто качественно новое. Национальные рынки труда утрачивают свою обособленность, замкнутость, и интегрированный рынок трудовых ресурсов становится национальным образованием. В основе его формирования лежит мобильность граждан государств, вошедших в Евразийский экономический союз, обеспечиваемая инструментами согласованной миграционной и социальной политики, международно-правовыми основами регулирования рынка труда, которые ориентированы на соблюдение баланса экономических и социальных интересов стран интеграционного союза. В настоящей работе отражена динамика развития рынка труда и занятости государств-членов ЕАЭС, выявлены проблемные звенья нового интеграционного пространства. Ключевое внимание направлено на анализ численности экономически активного населения, а также отдельно на анализ численности занятого населения/безработных, уровень заработной платы каждого государства-члена ЕАЭС на основе статистических данных Евразийской экономической комиссии. Авторами были замечены и прокомментированы основные моменты отличия динамики развития вышеуказанных показателей.

Ключевые слова: Евразийский экономический союз, рынок труда, занятость, безработица, заработная плата, население, деятельность. 